\title{
Effects of Heavy Metals on the Activity of Catalase and Glutathione-S-Transferase in Nile Tilapia Fish (Oreochromis niloticus)
}

\author{
Le Thu Ha, Bui Thi Hoa, Pham Thi Dau* \\ VNU University of Science, 334 Nguyen Trai, Thanh Xuan, Hanoi, Vietnam
}

Received 28 September 2021

Revised 04 November 2021; Accepted 09 November 2021

\begin{abstract}
This study evaluated the response of antioxidant enzymes, such as Catalase (CAT) and Glutathione-S-transferase (GST) in freshwater Nile tilapia fish Oreochromis niloticus (O. niloticus) exposed to heavy metals (HMs) including copper $(\mathrm{Cu})$, lead $(\mathrm{Pb})$ and cadmium (Cd). Fish were expose to various concentrations of $\mathrm{Cu}^{2+}, \mathrm{Pb}^{2+}(0,0.02,0.05,0.2 \mathrm{mg} / \mathrm{l})$ and $\mathrm{Cd}^{2+}(0,0.005,0.01,0.05 \mathrm{mg} / \mathrm{l})$ for $15,30,45$ and 60 days. The results indicated that enzyme activity was varied according to the exposure time, concentration and type of heavy metals. CAT activity increased significantly beginning at day 45 of HMs exposure. After 60 days of exposure, CAT activity was steady with $\mathrm{Cu}$ and $\mathrm{Pb}$ but inhibited by $\mathrm{Cd}$. While, GST induction was earlier observed from day 15 of HMs exposure. The increase of GST activity was found with the increase of exposure time in the treatment with $\mathrm{Cu}$ and $\mathrm{Cd}$ but not with $\mathrm{Pb}$. Interestingly, GST activity was inhibited by $\mathrm{Pb}$ at longer exposures (45 and 60 days). Among tested metals, $\mathrm{Cu}$ has weaker effects on the activity of CAT and GST in comparison with $\mathrm{Pb}$ and $\mathrm{Cd}$ suggesting that these enzymes were less sensitive to $\mathrm{Cu}$ than other tested metals.
\end{abstract}

Keywords: Heavy metal, Catalase, Glutathione-S-Transferase, Oreochromis niloticus.

\section{Introduction}

Copper, lead and cadmium are the most hazardous HMs that found in both aquatic and terrestrial ecosystems [1]. HMs enter, bioaccumulate and cause toxicological effects in living organisms [2]. It has been reported that HMs affect components of the cells such as

\footnotetext{
${ }^{*}$ Corresponding author.

E-mail address: phamthidau1204@gmail.com

https://doi.org/10.25073/2588-1140/vnunst.5339
}

lysosomes, mitochondria, nuclei and enzymes,... causing neurotoxicity, cellular function loss, cell damage and carcinogenesis [1]. These effects were used as biomarkers for metal exposure and their toxicity. Metal toxicity induces the production of free radicals which leads to DNA damage, alteration of homeostasis and stimulate lipid peroxidation [3]. Living organisms were protected from these stress by activating antioxidant defence systems [2]. GST and CAT are two important antioxidant enzymes which have been 
extensively used as biomarkers for metal exposure [4].

In waterbodies, HMs come from domestic, industrial, agricultural and other human activities [5], accumulate in aquatic organisms and affect not only their growth, development, reproduction but also on the health of human through the food chains $[1,5]$. Among aquatic species, fish plays an important role in energy transfer and have higher HMs accumulation due to its high level in the food web. HMs accumulation in fish is different according to species, organs and type of metals $[6,7]$. The freshwater Nile tilapia fish (O. niloticus) is an important species for commercial products in Asian countries including Vietnam. Our previous study showed that the accumulation of $\mathrm{Cu}, \mathrm{Cd}$ and $\mathrm{Pb}$ were found in $O$. niloticus sampling from some lakes in Hanoi, Vietnam was site-dependent [7]. An association between the alteration of GST activity and metal accumulation was found in $O$. niloticus collecting in Nhue-Day river basin [8].

Therefore, this study investigated the activity of GST and CAT enzymes in $O$. niloticus exposed to $\mathrm{Cd}, \mathrm{Cu}$ and $\mathrm{Pb}$ in various exposure periods in order to evaluate the potential effects of HMs on the antioxidant defence responses and physiological consequences of $O$. niloticus.

\section{Methodology}

Nile tilapia fish (O. niloticus) (weight of $7.81 \pm 1.31 \mathrm{~g}$ and age, 60-70 days) were purchased from the Research Institute for Aquaculture No.1 (Bac Ninh, Vietnam). Fish were acclimated under laboratory conditions for ten days prior to the experiments. Fish were fed with commercial food twice per day at daily rate of $3-4 \%$ body weight throughout the experiment [9]. $\mathrm{CuSO}_{4}, \quad \mathrm{~Pb}\left(\mathrm{NO}_{3}\right)_{2}$ and $\mathrm{Cd}\left(\mathrm{NO}_{3}\right)_{2}$ were used as test substances which were prepared in tap water to obtain the following final dissolved concentrations: 0 , $0.02,0.05,0.2 \mathrm{mg} / \mathrm{l} \mathrm{Cu}^{2+}$ or $\mathrm{Pb}^{2+}$; or $0,0.005$, $0.01,0.05 \mathrm{mg} / \mathrm{l} \mathrm{Cd}^{2+}$. These concentrations of
HMs were lower than the regulation levels of National technical regulation on surface water quality (QCVN 08:2008/BTNMT). For the enzyme activity test, 40-45 acclimatized fish were distributed randomly into tanks (100L) which contained the above mentioned concentrations of HMs. At the end of the exposure period $(0,15,30,45,60$ days), five fish from each group were randomly taken out, dissected and their livers were collected into $2 \mathrm{~mL}$ Eppendorf tubes containing $500 \mu \mathrm{l}$ Dulbecco's Phosphate Buffered Saline (DPBS) and then stored at $-80{ }^{\circ} \mathrm{C}$ for enzyme activity analysis. Liver samples were defrosted on ice, homogenized and centrifuged twice at 9700 $\mathrm{rpm}$ for $15 \mathrm{~min}$ at $4{ }^{\circ} \mathrm{C}$. Supernatants were collected for the enzymatic assay using a Thermo Sciencetific ${ }^{\mathrm{TM}}$ Biomate spectrophotometer. The CAT activity was determined following the previous method of Aebi et al. with some modifications [10]. The reaction was started by mixing $0.5 \mathrm{ml}$ of UV assay substrate solution $\left(20 \mathrm{mM} \mathrm{H} \mathrm{H}_{2} \mathrm{O}_{2}\right)$ with $0.02 \mathrm{ml}$ sample and $0.48 \mathrm{ml}$ assay buffer $(0.1 \mathrm{M}$ $\mathrm{K}_{2} \mathrm{HPO}_{4}$ and $0.1 \mathrm{M} \quad \mathrm{KH}_{2} \mathrm{PO}_{4}, \mathrm{pH}$ 7.0). The absorbance was measured for 30 seconds at $240 \mathrm{~nm}$. The specific activity of CAT was calculated and expressed as units $/ \mathrm{min} / \mathrm{mg}$ protein. The GST activity was measured according to Habig et al., using 1- chloro-2,4dinitrobenzene (CDNB) as a substrate [11]. The reaction was started by mixing $0.98 \mathrm{~mL}$ reaction buffer (100 mM DPBS buffer ( $\mathrm{pH}$ 6.5), $200 \mathrm{mM}$ GSH and $100 \mathrm{mM}$ CDNB) with $0.02 \mathrm{~mL}$ sample. The absorbance was measured every one minute for $8 \mathrm{~min}$ at $340 \mathrm{~nm}$. The specific activity of GST was determined and displayed as $\mu$ moles of GSH-CDNB conjugate formed $/ \mathrm{min} / \mathrm{mg}$ protein. Data were processed by Excel software and statistical analyses were performed using two-way ANOVA (Bonfferroni post-tests) and presented by mean \pm SEM ( $n=5)$ using GraphPrism software.

\section{Results and Discussion}

The liver has better oxidative stress resistance and contains higher antioxidant 
enzymes than any other tissues and is usually recommended as an environmental indicator of pollution and its toxicity. Pollutant exposure stimulates the formation of oxidative stress and prompt antioxidant enzymes act as a defence mechanism in organisms. Therefore, enzyme activities in the liver are considered as sensitive biomarkers of hazardous effects from pollutants including HMs in waterbodies [4].

\subsection{The Effect of HMs on CAT Activity}

CAT is a primary antioxidant defense component, which prevents oxidative stress damage by decomposing hydrogen peroxide into oxygen and water [4]. CAT activity (means $\pm \mathrm{SD}$ ) in the liver of $O$. niloticus was different among exposure periods, concentrations, and types of metals (Figure 1). These activities ranged from $7.18 \pm 1.08$ to $93.01 \pm 14.06,16.05 \pm 2.52$ to $57.67 \pm 18.97$, and $10.32 \pm 3.02$ to $89.07 \pm 14.35$, in response to $\mathrm{Cu}, \mathrm{Pb}$, and $\mathrm{Cd}$, respectively. The increasing trend in CAT activity according to concentration and exposure time was observed in $\mathrm{Cu}$ treatment. This activity increased significantly after 45 and 60 days of exposure at the concentrations of $0.05 \quad(p<0.05)$ and $0.2 \mathrm{mg} / 1 \quad(p<0.001), \quad$ respectively. $\mathrm{Pb}$ significantly increased CAT activity from
$0.02 \mathrm{mg} / \mathrm{l}$ upward after $45(p<0.01)$ and 60 days $(p<0.001)$ of exposure. This activity was increased continuously at $0.05 \mathrm{mg} / \mathrm{l}$ of $\mathrm{Pb}$ for 45 days $(p<0.05)$. After that, CAT activity was not change when the concentration and exposure time of $\mathrm{Pb}$ increased, suggesting saturation occurred in the enzyme activity with these conditions. These data showed that the CAT activity was enhanced due to the increase in $\mathrm{Pb}$ concentration and exposure time.

Differing from $\mathrm{Cu}$ and $\mathrm{Pb}, \mathrm{Cd}$ showed a strange trend in CAT activity which increased on days 15 and 45 and was inhibited on days 30 and 60 of $\mathrm{Cd}$ exposure. However, CAT was raised insignificantly $(p>0.05)$ and then reduced slightly at a concentration of $0.05 \mathrm{mg} / \mathrm{l}$ $(p<0.01)$ of $\mathrm{Cd}$ exposure after 15 days. The inhibition of CAT activity was found at both of the high and low concentration and short and long $\mathrm{Cd}$ exposure times could be explained by the involvement of $\mathrm{Cd}$ accumulation, toxicity and detoxification, which causes a disturbance in the body and the synthesis of enzymes [4]. The effect of the CAT activity in $O$. niloticus was similar to that in common carp (Cyprinus carpio) and major carp (rohu Labeo rohita) by Cd treatment [12].
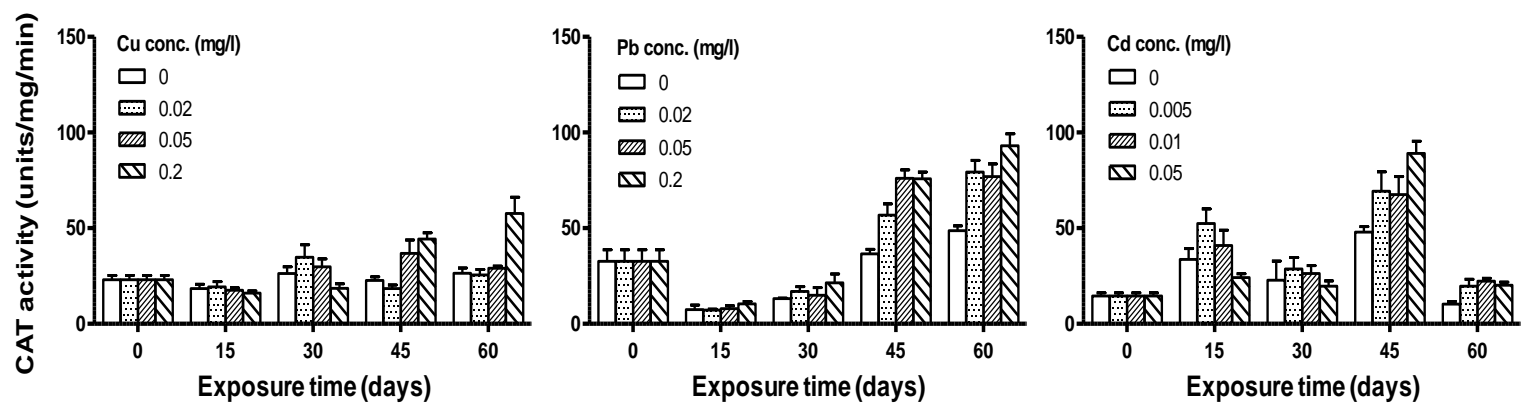

Figure 1. Liver CAT activity of $O$. niloticus exposed to HMs in different periods.

Data are expressed as mean $(n=5) \pm$ SEM.

\subsection{The effects of HMs on GST activity}

GST is an important antioxidant enzymes which protects organisms from oxidative stress damage by catalyzing the conjugation of glutathione with metals [4]. The GST activity (means $\pm \mathrm{SD}$ ) in the liver of $O$. niloticus also showed clear changes according to the metal concentration, exposure time and type of metals (Figure 2). These activities were $0.186 \pm 0.051$ to $1.280 \pm 0.396,0.025 \pm 0.010$ to $0.121 \pm$ 
0.020 , and $0.024 \pm 0.008$ to $0.891 \pm 0.286$ corresponding to the $\mathrm{Pb}, \mathrm{Cu}$ and $\mathrm{Cd}$ exposure, respectively. In general, the changes of GST activity occurred sooner than changes in CAT activity. $\mathrm{Cu}$ induced the GST at $0.2 \mathrm{mg} / \mathrm{l}$ after 30 days of exposure $(p<0.01)$. The longer the exposure time with $\mathrm{Cu}$ (60 days) the higher increase in GST activity, even at a low concentration of $0.02 \mathrm{mg} / \mathrm{l}(p<0.001)$. On the $60^{\text {th }}$ day of exposure, the GST activity was insignificantly increased in response to the increasing in $\mathrm{Cu}$ concentrations. Differing from CAT, GST activity was enhanced strongly by $\mathrm{Pb}$ from an earlier period (day 15) at $0.2 \mathrm{mg} / \mathrm{l}$ $(p<0.001)$. The increasing trend was presented in the first 30 days at $0.05 \mathrm{mg} / \mathrm{l}(p<0.05)$. Interestingly, this trend dropped to the level as before exposure to $\mathrm{Pb}$ at later periods (days 45 and 60). Compared with CAT, Cd exposure enhanced $(p<0.001)$ GST activities at the all concentrations and the exposure periods. The increase of GST activity represented the function of GST activity in oxidative stress and in protecting $O$. niloticus from damages by $\mathrm{Cd}$ exposure when CAT was repressed (at 0.05 $\mathrm{mg} / \mathrm{l})$. The GST activity of $O$. niloticus was similar to that of common carp (Cyprinus carpio) exposed to $\mathrm{Pb}$ and $\mathrm{Cd}$ [13]. GST activity was time dependent but not dose dependent in response to HMs treatment.
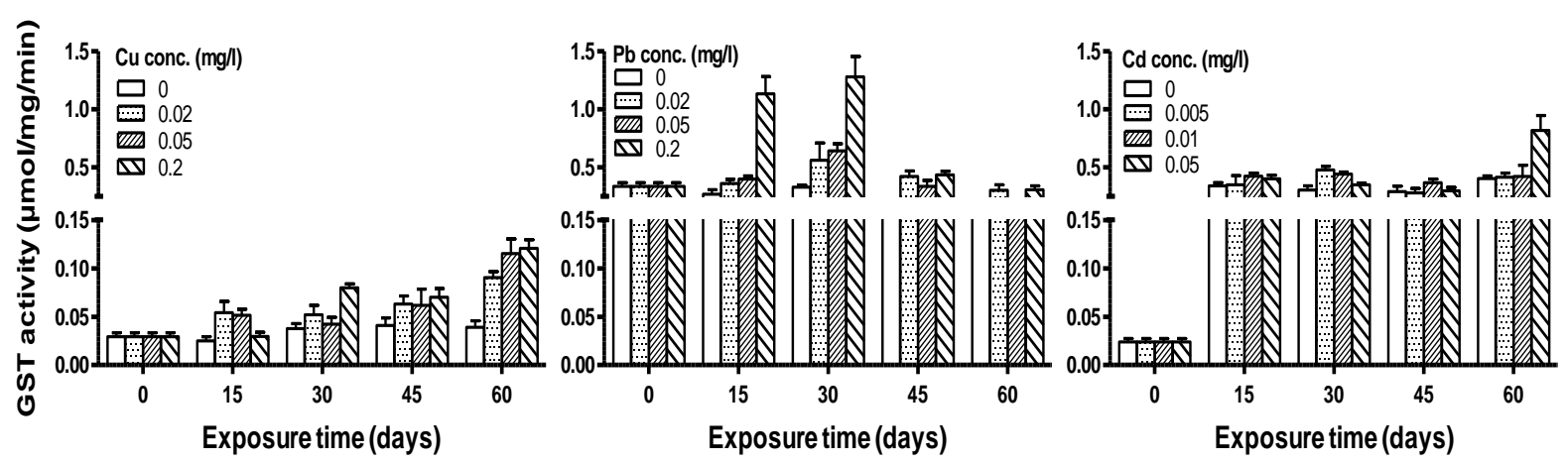

Figure 2. Liver GST activity of $O$. niloticus exposed to $\mathrm{Pb}, \mathrm{Cu}$ and $\mathrm{Cd}$ in different periods. Data are expressed as mean $(n=5) \pm$ SEM.

\subsection{Correlation between Enzymatic Activity and Bioaccumulation}

Our data displayed not only the activation but also the repression of enzyme activity by HMs exposure, suggesting that the activity changes might be related to the accumulation of HMs in the organism. Many scientists have been concerned about the relationship between HMs accumulation and enzyme activity in various species $[8,14,15]$. To examine whether the accumulation of $\mathrm{Cu}, \mathrm{Pb}$, and $\mathrm{Cd}$ affects alteration in the activity of CAT and GST, the Pearson's correlation test for the relationship between enzyme activity and HMs accumulation in muscle was performed (data not shown). The results of the relationships are shown in Table 1 . The correlation analyses indicated that changes in CAT activity were related to changes in accumulation of $\mathrm{Pb}$ $(\mathrm{r} \approx 0.66, \mathrm{p} \approx 0.002)$ and $\mathrm{Cu}(\mathrm{r} \approx 0.56$, $\mathrm{p} \approx 0.011)$. Meanwhile, GST showed a positive correlation $(\mathrm{r} \approx 0.81, \mathrm{p}<0.0001)$ for $\mathrm{Cu}$ and $\mathrm{a}$ weaker correlation for $\mathrm{Cd}(\mathrm{r} \approx 0.55, \mathrm{p} \approx 0.012)$. These correlations were not tight because the HMs accumulation in muscle was tested. Therefore, the accumulation of HMs in other organs with high accumulation potential should be further studied. Collectively, the accumulation of HMs in the muscle is also an additional factor to the metal-specific enzyme activity alteration. The data showed that $\mathrm{Cu}$ 
accumulation in muscle was correlated with both CAT and GST of $O$. niloticus in laboratory conditions. Our findings contradicted with previous publication, which showed that $\mathrm{Cu}$ accumulation has no correlation with GST activity in different tissues of this species collected from the Nhue-Day River [8]. However, our results were in line with $\mathrm{Cu}$ and $\mathrm{Pb}$ but not with $\mathrm{Cd}$ treatment for Brown Mussels (Perna perna), which showed a high correlation $(\mathrm{R}>0.92, \mathrm{p}<0.01)$ of the CAT activity in tissues with the metal accumulation [15]. Together with these findings, our data might suggests enzyme activity was changed not only by the accumulation of metal but also by other factors such as the form of metal chemicals, characteristics of organisms, and the living environment as reported in previous study $[4,12,13]$. The present data showed variability of baseline values of CAT and GST in $O$. niloticus which was demonstrated by the abnormality of enzyme activity without the HMs treatment in some periods. This phenomenon was also observed in common carp (Cyprinus carpio) and major carp (rohu Labeo rohita) species in our previous publications [12, 13]. These results might be due to abiotic environmental factors or the age of the fish [4].

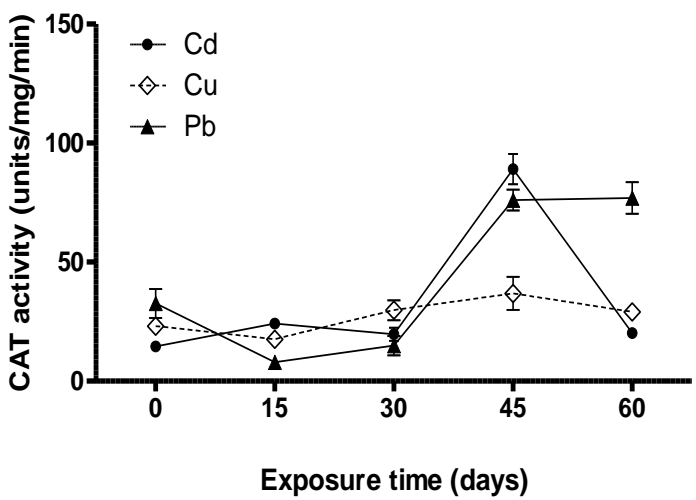

Table 1. Pearson correlation coefficients between HMs accumulation and enzyme activity

\begin{tabular}{|l|l|l|l|l|}
\hline \multirow{2}{*}{ Metals } & \multicolumn{4}{|c|}{ Biological parameters } \\
\cline { 2 - 5 } & \multicolumn{2}{|c|}{ CAT } & \multicolumn{2}{c|}{ GST } \\
\cline { 2 - 5 } & $\mathrm{R}$ & $p$ & $\mathrm{R}$ & $p$ \\
\hline $\mathrm{Pb}$ & 0.6553 & 0.0017 & 0.2303 & 0.3286 \\
\hline $\mathrm{Cu}$ & 0.5566 & 0.0108 & 0.8093 & $<0.0001$ \\
\hline $\mathrm{Cd}$ & 0.2821 & 0.2282 & 0.5520 & 0.0116 \\
\hline
\end{tabular}

3.4. Comparison of the Sensitivity of Enzymes with $\mathrm{HMs}$

To better understand the response of enzymes in $O$. niloticus to HMs exposure, the activity of CAT and GST were compared at the same concentration $(0.05 \mathrm{mg} / \mathrm{l})$ of different metals in several exposure periods. Among the test compounds, $\mathrm{Cu}$, which is an essential metal in organisms for enzymes to function normally, showed the lowest effect on both CAT and GST in comparison with other metals (Figure 3). During a short exposure time (day 15), there was an insignificant change in the activity of CAT and GST at all concentrations. Our results agreed with the results of a previous report that showed CAT activity in the liver of $O$. niloticus did not alter significantly at all tested concentrations of $\mathrm{Cu}$ [16].

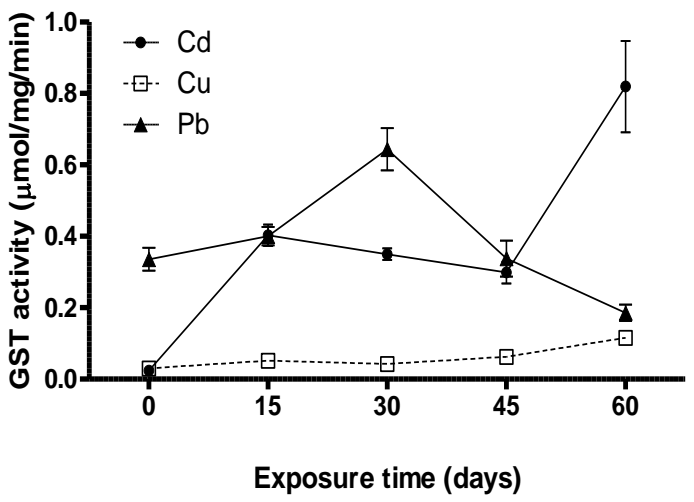

Figure 3. Comparison of enzymatic activities in livers of $O$. niloticus exposed with the same concentration $(0.05 \mathrm{mg} / \mathrm{l})$ of $\mathrm{Pb}, \mathrm{Cu}$ and $\mathrm{Cd}$ in different periods.

Data are expressed as mean $(n=5) \pm$ SEM. 


\section{Conclusion}

Our data revealed that the enzyme activities of $O$. niloticus exposed to $\mathrm{Cu}, \mathrm{Pb}$, and $\mathrm{Cd}$ varied depending on the concentrations, exposure times and types of metals. $\mathrm{Cu}$ showed a weaker effect on the activity of CAT and GST in comparison to $\mathrm{Pb}$ and $\mathrm{Cd}$, suggesting that these enzymes were less sensitive to $\mathrm{Cu}$ than other tested metals. Our findings also suggest that CAT and GST are sensitive biomarkers for metal biomonitoring in the aquatic environment. The elimination time of HMs, which is also an important factor for enzyme changes, should be a concern in future studies.

\section{Acknowledgements}

Authors are thankful to the Center for Life Science Research, VNU University of Science for the facility supports.

\section{References}

[1] J. Briffa, E. Sinagra, R. Blundell, Heavy Metal Pollution in the Environment and Their Toxicological Effects on Humans, Heliyon, Vol. 6, 2020, pp. 04691.

[2] M. Jaishankar, T. Tseten, N. Anbalagan, B. B. Mathew, K. N. Beeregowda, Toxicity, Mechanism and Health Effects of some Heavy Metals, Interdiscip. Toxicol., Vol. 7, 2014, pp. 60-72.

[3] M. Valko, H. Morris, M. T. Cronin, Metals, Toxicity and Oxidative Stress, Curr. Med. Chem., Vol. 12, 2005, pp. 1161-11208.

[4] A. Jemec, D. Drobne, T. Tišler, K. Sepčić, Biochemical Biomarkers in Environmental Studies - lessons Learnt from Enzymes Catalase, Glutathione S-transferase and Cholinesterase in Two Crustacean Species, Environ, Sci, Pollut, Res, Vol. 17, 2009, pp. 571-581.

[5] H. Ali, E. Khan, I. Ilahi, Environmental Chemistry and Ecotoxicology of Hazardous Heavy Metals: Environmental Persistence, Toxicity, and Bioaccumulation, J. Chem, 2019, pp. 6730305 .

[6] C. Marulius, W. Attu, S. Abdullah, K. Abbas, D. Batool, Antioxidant Enzymes Activity During
Acute Toxicity of Chromium and Cadmium to Channa marulius and Wallago Attu, Pak, J. Agric, Sci, Vol. 51, 2015, pp. 1117-1123.

[7] H. T. Le, H. T. T. Ngo, Cd, Pb, and $\mathrm{Cu}$ in Water and Sediments and Their Bioaccumulation in Freshwater Fish of some Lakes in Hanoi, Vietnam, Toxicol, Environ, Chem, Vol. 95, 2013, pp. 1328-1337.

[8] T. T. H. Ngo, L. Tuyet, H. T. Le, Effects of Heavy Metal Accumulation on the Variation of Glutathione S-transferases (GSTs) Activity in some Economic Fishes in Nhue-Day River Basin, VNU JS.: Nat, Sci, Technol, Vol. 32, 2016, pp. 83-95.

[9] A. M. A. Nagaawy, Accumulation and Elimination of Copper and Lead from O. Niloticus Fingerlings and Consequent Influence on Their Tissue Residues and some Biochemical Parameters, $8^{\text {th }}$ International Symposium on Tilapia in Aquaculture, Cairo, Egypt, 2008.

[10] H. Aebi, Catalase in Vitro, Methods Enzymol, Vol. 105, 1984, pp. 121-126.

[11] W. H. Habig, M. J. Pabst, W. B. Jakoby, Glutathione S-Transferases: The First Enzymatic Step in Mercapturic Acid Formation, J. Biol, Chem, Vol. 249, 1974, pp. 7130-7139.

[12] P. T. Dau, T. T. Nhung, T. T. Ha Lt., Effect of Cadmium and Lead on the Activities of Catalase in Cyrinus carpio and Labeo rohita, VNU JS.: Nat, Sci, Technol, Vol. 30, 2014, pp. 89-94.

[13] P. T. Dau, N. T. Huyen, L. T. Ha, Changes of Glutathione-S-transferase Activity by Cadmium and Lead in Freshwater Fish, VNU JS.: Nat, Sci, Technol, Vol. 30, 2014, pp. 16-20.

[14] D. Maharana, K. Jena, N. M. Pise, T. G. Jagtap, Assessment of Oxidative Stress Indices in a Marine Macro Brown Alga Padina tetrastromatica (Hauck) from Comparable Polluted Coastal Regions of the Arabian Sea, West Coast of India, J. Environ, Sci (China), Vol. 22, 2010, pp. 1413-1417.

[15] K. Boudjema, S. Kourdali, N. Bounakous, A. Meknachi, A. Badis, Catalase Activity in Brown Mussels (Perna perna) under Acute Cadmium, Lead, and Copper Exposure and Depuration Tests, J. Exp, Mar, Biol, Ecol, 2014, pp. 830657.

[16] G. Atli, M. Canli, Enzymatic Responses to Metal Exposures in a Freshwater Fish Oreochromis niloticus, Comparative Biochemistry and Physiology, Regul, Toxicol, Pharmacol, CBP, Vol. 145, 2007, pp. 282-287. 